\title{
The Role of Employee Engagement Mediates the Relationship of the Work Environment, Teamwork on Employee Performance
}

\author{
Paulino Mendonca 1, I Gede Riana ${ }^{2}$, Augusto da Conceição Soares ${ }^{3}$ \\ Master's Program, Institute of Business (IOB), Timor-Leste ${ }^{1}$ \\ Faculty of Economics and Business UDAYANA University, Bali, Indonesia ${ }^{2}$ \\ Master'sProgram, Institute of Business (IOB), Timor-Leste ${ }^{3}$
}

\begin{abstract}
Paulino Mendonca, Master Program in Management Sciences, Magister Program Institute of Business IOB. The Role of Employee Engagement Influence Work Enviroment, Teamwork on Employee Performance. Commission of Supervisor I: Dr. I Gede Riana, SE., MM, Commission of Supervisor II: Dr. Augusto Da C. Soares, SE., MM.

This study aims to analysis (1) influence of the work environment on employee performance, (2) influence of the work environment on employee involvement, (3) influence of teamwork on employee performance, (4) influence of teamwork on employee involvement, (5) the effect of employee involvement on employees performance, (6) the role of employee involvement mediates the working environment relationship on employee performance, (7) the role of employee involvement mediates teamwork relationship to employee performance.

The population in this study was 680 of all MAP employees at the Dili, the sample using the slovin formula so as to get 156. Data were analyzed using the Smart-PLS

The research findings the work environment, teamwork, influence positive not significantly to employee performance. This research shows that work environment, teamwork is not able to improve employee performance. The effect of work involvement on employee performance found that involvement had a positive significant effect on employee performance. The role of employee involvement mediates the working environment relationship, teamwork is full mediation. Keywords: Work Environment, Teamwork, Employee Engagement, Employee Performance.
\end{abstract}

\section{INTRUDUCTION}

Today's public services are needed to move quickly, adaptively, precisely, and efficiently. In an era marked by rapid and continuous change, knowledge capital must be maintained in order to be productive and responsive to the needs of the organizationAmin, et al. (2014). Every organization in carrying out its activities must have a goal to be achieved, to achieve or realize 
these goals every organization must be clever in choosing a strategy, especially human resource planning which is essentially focused on certain steps taken by management.

According to Mina et al. (2013)To build quality public service performance, organizations should be organized to be able to provide space for all employees to improve their best performance. In this case it will clearly require professionalism and responsibility. Professionalism and responsibility need to be improved by managing human resources (employees) in government organizations, so that they have high performance. In order to achieve the goals and objectives set one of the things that should be the main concern of the organization is the work environment, teamwork and employee involvement in work.

A conducive work environment provides a sense of security and allows employees to work optimally. The work environment can affect employee emotions. If the employee likes the work environment where he works, then the employee will feel comfortable at work, doing activities so that work time is used effectively.

Teamworkgenerate positive synergies through coordinated effort. Individual efforts produce a level of performance that is higher than the number of individual inputs. The extensive use of teams produces the potential for an organization to produce many greater results without increasing input. Teamwork will be superior to individual performance if the task that has to be done requires multiple skills. According to Sadat \& Fesharaki (2012) someone who is not involved in participating in the organization will assume that the work is considered not important for selfesteem and does not have an emotional attachment to the organization which ultimately has a negative impact on declining performance.

Involvement refers to employee participation in decision making and problem solving, and increased autonomy in the work process. As a result, employees are expected to be more motivated, more committed, more productive, and more satisfied with work and contribute as a whole, participate in work and work flexibility(Rangus et al., 2016; Permarupan, et al., 2013; M \& Rao, 2014; Rahati et al., 2015).

Ministerio Agricultura e Pescas is a government institution that operates in the agriculture and fisheries sector which has a very important role in national economic development. The quality of human resources as one of the factors that support employee improvement. This, of course, is inseparable from the effect of a shift in orientation and national development strategies towards good governance that requires openness, democratization, public participation and excellent 
service to the community, as a result of increasing public awareness that they have the right to obtain better service from the government.

Various problems that occur in the Ministerio Agricultura e Pescas environment one of the most fundamental is the performance of employees that is less than the maximum. This relates to the work output (output) where the poor bureaucracy and the low quality of public services and public confidence in the administration of government. From the phenomena that occur in the Ministerio Agricultura e Pescas environment, it can be concluded that how important aspects of human resources are in the management of good government organizations. Employees in the organization are required to be able to actualize themselves as quality human resources and employees should be involved in a job in accordance with the orders from their superiors to participate actively in accordance with their abilities in order to work better.

\section{HYPOTHESIS}

Employee performance is a variable that is the focus of this study. This is based on a phenomenon related to less than optimal performance of government organizations in the Ministerio Agricultura e Pescas of Timor-Leste. To give clear direction to this empirical research it is necessary to build hypotheses from the study of literature, literature and the results of empirical research.

The hypothesis that is built is then tested for its truth through the process of analysis using data obtained from research subjects in the field with interviews, documentation and questionnaires. For answers to the formulation of the problem, this study uses descriptive analysis to explain the effect of the variables, as well as to determine the effect of each exogenous variable on endogenous variables carried out quantitative analysis using Partial Least Square (PLS). Overall the results of the study will produce a conclusion in response to the problem under study, the conclusion will later be used as an evaluation material for policy making for the government environment in order to support the improvement of employee performance development in Timor-Leste.

Conceptual framework is a relationship or relationship between one or several concepts with other concepts of the problem under study. The universal phenomenon of employee performance is less than the maximum impact on the quality of work, the quantity of work, the presence of employees at work, accuracy in completing work and cooperation in organizational 
agenciesGüngör (2011). In this study employee performance is defined as a description of the level of achievement of the implementation of activities, programs, policies, using a number of resources to achieve the goals set. In other words, performance is a function of job ability in accepting work goals, levels of achievement, goals and interactions between goals and work.

Three variables are able to influence employee performance based on several theories of the research findings that have been described, then in this section the researcher determines that the work environment, teamwork and employee involvement, are important to explain. Based on several theories of the research findings that have been described, then in this section the researcher determines the framework of the research concept that is related to the work environment, teamwork, employee involvement and employee performance variables.

Based on the explanation above, the concept of this research model can be seen in Figure 2.1

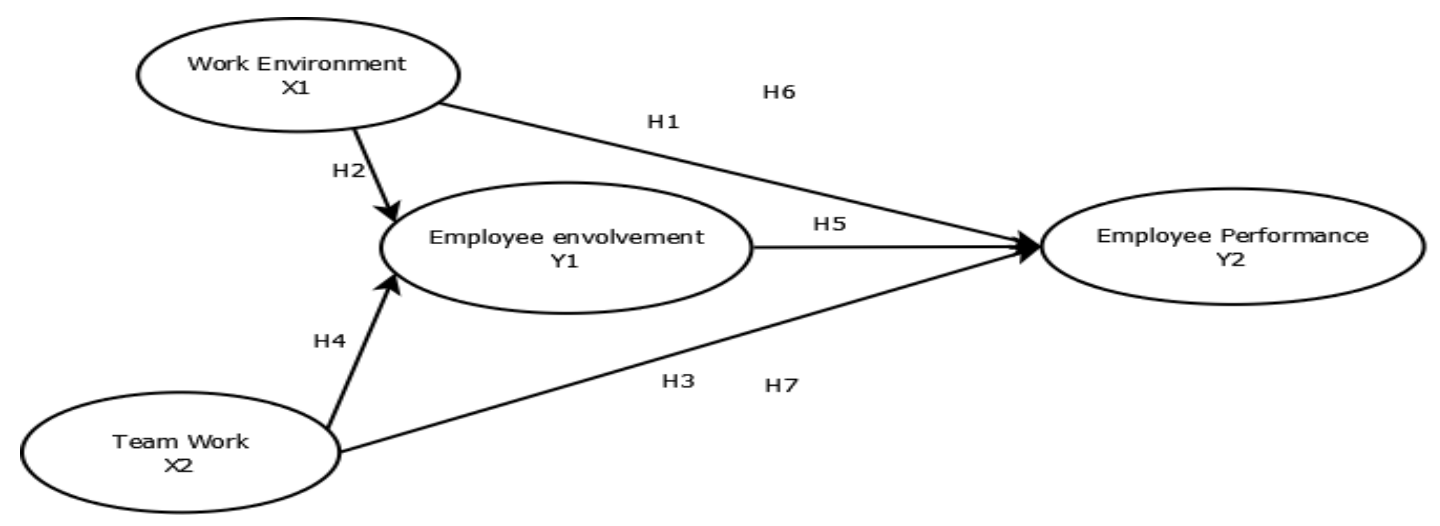

Figure 2.1. Research Model

\subsection{The influence of the work environment on employee performance.}

A conducive work environment provides a sense of security and allows employees to work optimally. The work environment can affect employee emotions, if the employee likes the work environment where he works, then the employee will feel comfortable at work for activities so that working time is used effectively and optimally employee performance is also high.

The work environment includes work relationships formed between fellow employees and work relations between subordinates and superiors as well as the physical environment where employees work Mateo et al., 2013; Jayaweera, 2015; Saputro, 2016, Pawirosumarto \& Gunawan, 2017; Adam, \& Boateng, 2017; Meriläinen \& Kõiv, 2018; Bibi, \& Majid, 2018). Research 
Jayaweera, 2015;Rohail et al., 2017; and Raziq \& Maulabakhsh, 2015 has proven that a pleasant work environment is very important to encourage the most productive levels of employee performance.

Based on the description above, as well as the support of the results of previous studies, it can be stated the following research hypotheses:

H1 : The work environment has a positive and significant effect on employee performance.

\subsection{Effect of work environment on employee involvement.}

The work environment is a place where employees carry out work activities. The work environment can bring positive and negative impacts on employees in order to achieve their work. The work environment in an organization is very important for management to consider. Even though the work environment does not carry out the production process in an organization, the work environment has a direct influence on the employees who carry out the production process (Mohd \& Zailan, 2016; Tyagi, 2017), employees who care about the work environment both for personal comfort and to make it easier to do tasks better.

According to Pawirosumarto \& Gunawan, 2017; Adam, \& Boateng, 2017; Meriläinen \& Kõiv, 2018; Bibi, \& Majid, 2018)that a good work environment, such as an attractive and clean environment, encourages employees, individuals to complete their work effectively. According toAdam et al. (2017), Organizational environment plays an important role for employees. Employees have a large number of work alternatives, so the environment at work is an important factor for accepting and / or maintaining employment. The quality of the environment at work can easily determine the level of employee motivation, performance and productivity.

Based on the description above, as well as the support of the results of previous studies, it can be stated the following research hypotheses:

H2 : The work environment has a positive and significant effect on employee involvement.

\subsection{The effect of teamwork on employee performance.}

In short definition, teamworkis a set of values, attitudes and behaviors in a team. So it does not always consist of a group of people with the same style, attitude or way of working. Through 
collaboration and sharing of knowledge and skills, a team is often able to complete tasks effectively, rather than being carried out by an individual.

Teamwork are groups whose individual efforts produce higher performance than the number of individual inputs Raziq \& Maulabakhsh, (2015). This means that the performance achieved by a team is better than the performance per individual in an organization (Gil, \& Peiró, 2005; Walter et al., 2019; Levi \& Slem, 1995; Mahabeer \& Govender, 2013; Farh \& Tesluk, 2012; Henttonen, \& Johanson, 2013). The extensive use of teams produces the potential for an organization to produce many greater results without increasing input. Teamwork will be superior to individual performance if the task has to be done according to multiple skills.

Based on the description above, as well as the support of the results of previous studies, it can be stated the following research hypotheses:

H3 : Teamwork positive and significant effect on employee performance.

\subsection{The effect of teamwork on employee involvement.}

Teamwork are groups whose individual efforts produce higher performance than the number of individual inputs Walter et al., (2019). This means that the performance achieved by a team is better than the performance of individuals in an organization. One indicator of effective interpersonal functions of employees at work is the effectiveness of teamwork, or the extent to which employees work well with other team members and meet their needs effectively.

Teamwork effectiveness is achieved when employees effectively exchange information and resources with, collaborate actively, and respond to the needs and requests of other team members in an appropriate manner Farh \& Tesluk, (2012). Overall the team is organizing employees in an effort to utilize their collective competence at workMahabeer \& Govender, (2013).

Mahabeer \& Govender, (2012) teamwork is a person who is sportive, sensitive and happy to get along, and is able to recognize the flow of emotions that is hidden in the team very clearly. Teamworkgenerate positive synergies through coordinated effort. Their individual efforts produce a level of performance that is higher than the number of individual inputsGil, \& Peiró, (2005); Walter et al., (2019).

Based on the description above, as well as the support of the results of previous studies, it can be stated the following research hypotheses: 
H4 : Teamwork positive and significant effect on employee involvement.

\subsection{The effect of employee involvement on employee performance.}

Employee involvement provides a significant influence on employee performance which means the higher level of employee involvement in an organization will increase employee productivity and organization. Employee involvement or participation in work activities is important to note because with the involvement of employees will cause them to be willing and happy to work together, both with the leadership or with fellow colleagues (Lin, 2006; Mahabeer \& Govender, 2012; Ahya, 2016; Bosak et al., 2017; Rangus \& Slavec, 2017). Job involvement has been linked to work related behavior as well as being the next predictor of work related outcomes. Employees who have a great emotional involvement towards the organization's goals will provide benefits to the organization, namely increased work productivitySmell \& Saufi, (2013).

Based on the description above, as well as the support of the results of previous studies, it can be stated the following research hypotheses:

H5 : Employee involvement has a positive and significant effect on employee performance.

\subsection{The role of employee involvement mediates the relationship of the work environment to employee performance.}

Employee involvement is a form of commitment of an employee in involving the role and concern for work both physically, knowledgeally and emotionally, so that the work he does is very important and has a strong belief to be able to complete it. According to Rahati et al., (2015), work involvement is the mental and emotional involvement of people in group situations that encourage them to contribute to group goals and the various responsibilities for achieving those goals. According toM \& Rao, (2014), work involvement is a degree of someone psychologically interpreting himself with work and considers the level of performance as important for self-esteem.

Based on the description above, as well as the support of the results of previous studies, it can be stated the following research hypotheses:

H6 : The role of positive employee involvement mediates the relationship between work environment and employee performance 


\subsection{The role of employee involvement mediates the effect of teamwork on employee performance.}

Work engagement is defined as a measure to which individuals psychologically side with their work and consider the level of performance achieved as an important self-esteem Robbins \& Judge, (2008: 100). Work involvement is an employee who has a high work involvement in his work characterized by employees having a high concern for work, a feeling of being psychologically attached to the work he is doing and a strong belief in his ability to complete workHernaus \& Mikulić, (2014).

According to Mahabeer \& Govender, (2012), work involvement as the values of "the goodness and importance of work" that internalize among people. Work engagement will not only result in timely attendance at work, employee feelings of success in their work, and a sense of goal achievement and optimism about the organization but will also lead to a belief in the compatibility between personal goals and organizational goals (Sofijanova et al., 2013; Sadat \& Fesharaki, 2012; Rahati et al., 2015).

Based on the description above, as well as the support of the results of previous studies, it can be stated the following research hypotheses:

H7 : The role of positive employee involvement mediates the relationship between teamwork and employee performance

\section{RESEARCH METHODS}

This research takes place at the East Timor public sector government office, with a focus of study on the Ministerio Agricultura e Pescas of Timor-Leste. The object of research is the work environment, teamwork, employee involvement and employee performance. The population in this study were 680 employees of Ministerio Agricultura e Pesca employee The research sample is part of the population that can be represented in the study. The sample size in this study was determined based on the Slovin formula sample size 156.

The data analysis method uses Structural Equation Modeling (SEM) -Partial Least Square (PLS). Based on the framework of the research concept, the research model will be analyzed using SEM-PLS. Descriptive analysis was carried out with the SPSS program, whereas inferential analysis was carried out with the SmartPLS 3.0 program. 


\section{RESULTS AND DISCUSSION}

Characteristics of respondents in this study were based on gender, age group, marital status, education level, years of service. The question of the characteristics of respondents becomes important in this study because it can explain or provide a description of the identity of the respondents in the study, because by describing the identity of the respondents in the study, it will be known the composition and position of the respondents in this study, which in turn can be analyzed to draw a conclusion to support this research.

\subsection{Reliability and Validity}

Measurement of the outer model based on the criteria of convergent validity, discriminant validity, composite reliability, and Cronbach's Alpha, shows that it has met the criteria for testing validity and reliability, then each indicator can be declared valid and reliable. Discriminant validity is performed to compare the square root of the variance extracted ( $\sqrt{\mathrm{AVE}}$ ) coefficient of each latent variable with the correlation coefficient between the other latent variables in the model. The recommended AVE value is greater than 0.05 (Lathan and Ghozali., 2012: 79), so that variable indicators have good discriminant validity. The results of the discriminant validity calculation are shown in Table I.

Composite reliability and Cronbach's Alpha are reliability measurements between the indicator block blocks that make up the research model. Reliability of composite and Cronbach's Alpha is considered good if the value is above 0.70. Based on the results of data calculations using the SmartPLS 3.0 program, composite reliability and Cronbach's Alpha values are shown in Table 1.

Table I. The Composite Reliability and Cronbach's Alpha variables work environment, teamwork, employee involvement, and employee performance

\begin{tabular}{|l|c|c|c|}
\hline Variable & $\begin{array}{c}\text { Composite } \\
\text { Reliability }\end{array}$ & Cronbach's Alpha & AVE \\
\hline Work environment (X1) & .884 & .858 & 0.533 \\
\hline Teamwork (X2) & 0.882 & 0.848 & 0.504 \\
\hline Employee involvement (Y1) & 0.848 & 0.759 & 0.583 \\
\hline Employee performance (Y2) & .897 & 0.867 & 0.523 \\
\hline
\end{tabular}

Source: data processed, 2019.

The structural model (inner model) is assessed to check how well the research model is formed using a number of variables. The testing criteria for assessing the model in this study are 
based on a number of criteria, namely: R-Square (R2), Q-Square Predictive (Q2), Goodness of Fit (GoF), and Effect size (f2). The results of data calculations using SmartPLS 3.0 are shown in Table II.

Table. II. $R$-Square (R2) ofemployee engagement variables, and employee performance

\begin{tabular}{|l|c|c|}
\hline \multicolumn{1}{|c|}{ Variable } & $R$-Square (R2) & Information \\
\hline Employee involvement (Y1) & 0.461 & High \\
\hline Employee performance (Y2) & .456 & High \\
\hline
\end{tabular}

Source: data processed, 2019.

Based on Table II, the value of R-Square (R2) for employee engagement variable (Y1) is 0.461 , employee performance is 0.456 (Y2). R2 value of 0.461 , for employee involvement means that $46.10 \%$ employee involvement is influenced by the work environment and teamwork, the rest $(53.39 \%)$ is another factor outside the research model. R2 value of 0.456 on employee performance variables means that employee performance of $45.60 \%$ is influenced by employee vacancies, the rest $(54.38 \%)$ is another factor. Referring to the criteria set by (Hair et al., 2010; Latan \& Ghozali, 2012: 85), that the R2 value is relatively high. Q2 calculation results show a value of $=0.7068$ which means that $70.68 \%$ of the relationship between latent variables can be explained strongly by the research model, while the remaining $29,32 \%$ is another factor that is not taken into account in the research model. GoF calculations are based on the R2 value and AVE value on each variable. GoF calculation results show a value of 0.4975 , based on GoF criteria according to Latan and Ghozali (2013: 86), the values above are classified as high GoF. This means that the research model has a high degree of accuracy.

The results of the structural model / inner model evaluation are measured by the criteria of R-Square (R2), Q-Square Predictive Relevance (Q2), and Goodness of Fit (GoF), then the measurement results can be stated in good categories. Because all the structural model evaluation criteria used (R2, Q2, and GoF) show good results, the research model that examines the relationship between variables work environment, teamwork, employee involvement, and employee performance including a good model.

Based on the two stages of model evaluation, namely the measurement model / outer model stage and the structural model / inner model stage, where both stages provide decent results, then it can be continued at the third stage, namely testing the research hypothesis. 


\subsection{Hypothesis Testing Results}

Testing the direct effect of each research hypothesis is evaluated in detail based on the results of testing research data that is processed with SmartPLS 3.0 software and the results are shown in Figure 4.1 and Table IV

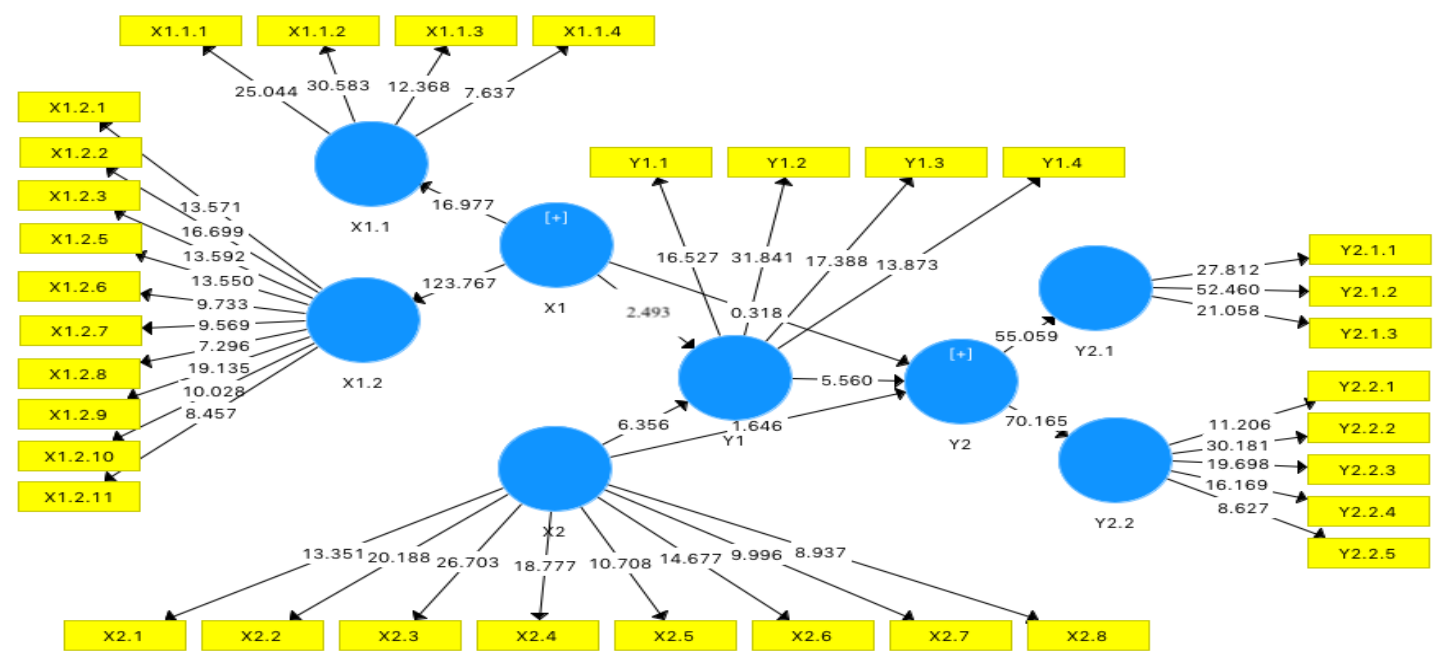

Figure 4.1: Path coefficient at $\alpha=0.05$.

Source: Data processed, 2019

Table. III. Direct influence between work environment, teamwork, employee involvement, on employee performance

\begin{tabular}{|l|l|l|l|l|}
\hline $\begin{array}{c}\text { Relationship } \\
\text { between } \\
\text { variables }\end{array}$ & $\begin{array}{c}\text { Koef. direct } \\
\text { influence }\end{array}$ & T-statistics & \multicolumn{1}{|c|}{ T-table } & \multicolumn{1}{|c|}{ Information } \\
\hline $\mathrm{X} 1 \rightarrow \mathrm{Y} 1$ & 0.238 & 2,493 & $>1.96$ & Significant \\
\hline $\mathrm{X} 1 \rightarrow \mathrm{Y} 2$ & 0.036 & 0.318 & $<1.96$ & Not significant \\
\hline $\mathrm{X} 2 \rightarrow \mathrm{Y} 1$ & 0.548 & 6,356 & $>1.96$ & Significant \\
\hline $\mathrm{X} 2 \rightarrow \mathrm{Y} 2$ & 0.217 & 1,646 & $<1.96$ & Not significant \\
\hline $\mathrm{Y} 1 \rightarrow \mathrm{Y} 2$ & .484 & 5,560 & $>1.96$ & Significant \\
\hline
\end{tabular}

Source: data processed, 2019.

Caption: $\mathrm{X} 1$ = work environment, $\mathrm{X} 2$ = teamwork, $\mathrm{Y} 1=$ employee involvement, $\mathrm{Y} 2=$ employee performance. 
Based on the results of data processing shown in Figure 4.1 and Table III, it shows that:

The work environment shows a positive and not significant effect on employee performance where the path coefficient shown is 0.036 with t-statistics of $0.303<1.96$. The results of this test indicate that Hypothesis $1(\mathrm{H} 1)$ which states that the value of the work environment has a positive and significant effect on employee performance is not accepted.

The work environment shows a positive and significant effect on employee involvement where the path coefficient shown is 0.238 with t-statistics of 2.493>1.96. The results of this test indicate that hypothesis $2(\mathrm{H} 2)$ which states that the work environment has a positive and significant influence on employee involvement can be accepted.

Teamworkshows a positive and not significant effect on employee performance where the path coefficient shown is 0.217 with t-statistics $1.646<1.96$. The results of this test prove that hypothesis 3 (H3) which states that teamwork has a positive and not significant effect on employee performance is not acceptable.

Teamworkshows a positive and significant effect on employee involvement where the path coefficient shown is 0.548 with t-statistics of 6.456> 1.96. This test proves that hypothesis 4 (H4) which states that teamwork has a positive and significant effect on employee involvement can be accepted.

Employee involvement shows a positive and significant effect on employee performance where the path coefficient shown is 0.484 with t-statistics of 5.604> 1.96. The results of this test prove that hypothesis 5 (H5) which states that employee involvement has a significantly positive effect on employee performance can be accepted.

The indirect effect of hypothesis 6 (H6), namely: the role of involvement in mediating the relationship of work environment on employee performance, and hypothesis $7(\mathrm{H} 7)$, namely: the role of employee involvement mediating teamwork on employee performance. Each indirect influence hypothesis is evaluated in detail based on the results of processing research data that is processed with SmartPLS 3.0 software and the results are shown in Table IV 
Table IV. The indirect effect of the work environment, teamwork, variables on employee performance

\begin{tabular}{|l|c|c|c|l|}
\hline $\begin{array}{c}\text { Relationship Between } \\
\text { Variables }\end{array}$ & Mediation Variable & Indirect & t-statistics & Information \\
\hline $\mathbf{X 1}$-> Y1 -> Y2 & Y1 & 0.078 & 3,735 & Significant \\
\hline $\mathbf{X 2}$-> Y1 -> Y2 & Y1 & 0.265 & 3,835 & Significant \\
\hline
\end{tabular}

Source: data processed, 2019.

.Employee involvement (Y1) is mediating the effect of the work environment (X1) on employee performance (Y2). This is indicated by the value of the path from the work environment to employee performance through involvement of 0.078 with a t-statistics value of 3.735> 1.96.

The results of this test illustrate that hypothesis 6 (H6) which states that employee involvement fully mediates (full mediation) the influence of the work environment on employee performance is acceptable. Employee involvement (Y1) is mediating the effect of teamwork (X2) on employee performance (Y2). This is indicated by the value of the path from teamwork to employee performance through employee involvement of 0.265 with a t-statistics value of 3.835> 1.96. If seen from another angle, where teamwork has a positive and not significant effect on employee performance, while involvement has a significant positive effect on employee performance, then employee involvement acts as a full mediation (full mediation) relationship between teamwork and employee performance.

\section{DISCUSSION}

In testing the data generated that the work environment as an exogenous variable has no significant positive effect on employee performance. A positive and insignificant work environment on employee performance proves that physical and psychosocial work conditions are based more on individuals to set specific targets in performance. This can prove that the employees at Ministerio Agricultura e Pescas have not been maximized in accessing the work environment properly and consistently in physical work conditions or psychosocial work conditions. Previous research that supports this result,Pawirosumarto, and Gunawan, (2017), showing that the work environment does not significantly affect employee performance at Parador Hotels and Resorts.

Based on this explanation, it can generally be said that this study confirms previous research that employees do not feel comfortable in the work environment. This study was unable to confirm a number of previous research findings which revealed that an employee's work 
environment could improve better performance in an employee, (Pawirosumarto, \& Gunawan, R. 2017; Saputro, TA, Paramita, 2016;Tyagi, V. 2017) and Jayaweera, 2015).

The work environment as an exogenous variable has a significant positive effect on employee involvement. This identifies that the work environment means that the better the work environment, the better the involvement of employees in work. A positive and significant work environment for employee involvement proves that the conditions in the workplace can affect employees both directly and indirectly in work wheresomeone will be seen attitudes, values, norms and feelings that are commonly owned by him at work. These conditions or situations that directly or indirectly affect the style of movement in organizational life because the work environment will always experience changes. This mattercan prove that the employees at the Ministerio Agricultura e Pescas can work well as desired, if employees feel safe and comfortable in a good and conducive work environment. There are previous studies that support this result, (Rangus and Slavec, 2017; Permarupan, and Saufi, 2013; Jayaweera, 2015), employee involvement is a factor that can support employee performance. Adam, Effah and Boateng, (2017) that the work environment can increase employee involvement, in increasing employee involvement an employee will feel comfortable and safe in the work environment under physical working conditions and psychosocial work conditions such as building maintenance, access to all facilities so as to improve one's competency at work.

Based on this description, in general it can be stated that the results of this study confirm a number of previous research findings which reveal that the work environment is able to provide encouragement to employee involvement so that employees can do their jobs better.

Teamworkas an exogenous variable has a positive and not significant effect on employee performance. This identifies that teamwork means that the better the teamwork, the better the employee's performance.

Teamworkpositive and insignificant effect on employee performance proves that work goals, contributions in the organization and participation in setting organizational goals always provide positive things for employees in carrying out their duties and responsibilities. Performance is the level of someone feeling synonymous with work, where performance will encourage someone that work is important to him. Work performance is a participatory process that uses employee input and is included to increase employee commitment to organizational success. Employee performance can provide a very large influence on the success of an organization in 
achieving its goals. This matter can prove that the employees at Ministerio Agricultura e Pescas in work performance become an employee's commitment to his work which is characterized by employees having high concern for work, there is a feeling of being psychologically attached to the work he is doing and a strong belief in his ability and realizing that his work performance is important for self-esteem. Previous research that supports this result (Farh, Seo and Tesluk, 2012) explains that teamwork has a very complex relationship to employee performance. Employee performance in doing work both individually and in groups to achieve common goals, has a positive impact on the performance of individuals and organizations in achieving organizational goals,Gil, and Peiró, 2005; Rangus and Slavec, 2017).

To improve employee performance, teamwork prioritizes good service to all employees, responsibility in teamwork, creating a climate of trust, open and honest communication, creating a focus on team members' attention.

Based on this description, in general it can be stated that the results of this study confirm a number of previous research results which revealed that teamwork is able to provide encouragement to employee performance so that employees can do their jobs better. The better teamwork at work, the better employee performance.

Teamworkhas a significant positive effect on employee involvement. This identified that teamwork meant that the better the teamwork, the better the employee involvement. Positive and significant teamwork for employee involvement in Ministerio Agricultura e Pescas, proves that teamwork can improve collaboration and communication within and between parts of the organization. Teamwork is a group where individual efforts produce higher performance than the number of individual inputs. Teamwork generates positive synergies through coordinated efforts.

The results of previous research are: teamwork contributes to increase employee engagement Anitha (2014), there is a significant relationship between teamwork and employee involvement. Workplace conditions play an important role for employees whether they want to continue working in the organization. Good teamwork can produce positive synergies through coordinated effort. Teamwork as a form of work in groups that must be organized and managed properly in the success of the organization.

Based on this description, in general it can be stated that the results of this study are able to confirm a number of previous research findings which reveal that teamwork can increase work 
engagement, so that employees can do their jobs better. The better the teamwork, the better the employee involvement.

Employee involvement has a positive and significant effect on employee performance. This identifies that employee involvement means that the better the employee involvement, the better the employee's performance. Positive and significant employee involvement on employee performance proves that employee involvement depends on clear goals for the job, understanding the work and contributing to work. The greater the employee's contribution to work, then all organizational needs will be met.This matter can prove that the employees at Ministerio Agricultura e Pescas showed high involvement so that it could affect work performance.

Based on this description, in general it can be stated that the results of this study confirm a number of previous studies which revealed that employee involvement in an employee is able to provide encouragement to performance so that employees can do their jobs better, Mohd Shah and Zailan, 2016;Mahabeer and Govender, 2013; Henttonen, Janhonen and Johanson, 2013; Dimming, 2013).

Statistical test results found that employee involvement mediates the influence of the work environment on employee performance. The results of hypothesis testing in Table IV where significant employee involvement is mediating the effect of the work environment on employee performance. In the hypothesis test shown in Table IV where the work environment has a significant effect on employee involvement, based on this it can be stated that employee involvement is a full mediation of the relationship of work environment to employee performance in Ministerio Agricultura e Pescas.

This means that employee involvement is a factor that can mediate the relationship between work environment and employee performance. While the hypothesis of employee involvement mediates the relationship of work environment to employee performance is proven, namely the effect of employee involvement on employee performance. Thus the statement that employee involvement is concluded has a significant effect on employee performance in this study. The results of the analysis get an estimate of the effect of employee involvement on employee performance is 0.484 with a positive sign. Thus it can be concluded that the increase in dimensions of employee involvement has a positive impact on employee performance. It can be proven that employee involvement is able to fully mediate the influence of the work environment, work environment on employee performance at Ministerio Agricultura e Pescas. This is shown from the 
results of the statistical tests in Table IV, where the work environment has a significant positive effect on employee involvement, as well as employee involvement has a significant positive effect on employee performance.

Employee involvement acts as a mediator of the relationship between teamwork and employee performance. If we look at the teamwork contribution, the total direct effect between teamwork and employee performance is 0.217 while the total indirect effect (work environment $\rightarrow$ employee involvement $\rightarrow$ work performance of employees) is 0.265 , meaning an increase of 0.484 points. This means that involvement can strengthen the relationship between teamwork and employee performance. Improved teamwork, coupled with stronger employee involvement, can improve employee performance for the better.

A number of previous research findings that are consistent with this research include (Walter et al., 2019; Gil, and Peiró, 2005; Adam, and Boateng, 2017; Raziq and Maulabakhsh, 2015; Permarupan, and Saufi, 2013; Sadat and Fesharaki, 2012).

\section{CONCLUSSION}

Based on the analysis and discussion as stated above, the following conclusions can be made:

The work environment does not have a significant positive effect on the performance of employees of Ministerio Agricultura e Pescas, meaning that the work environment is anything that is around the workers who can influence themselves in carrying out the tasks they carry. The work environment includes the place of work, facilities, and job aids, cleanliness, lighting, tranquility, including work relationships between people who are in the place but the environment in Ministerio does not fully support employee performance.

The work environment has a significant positive effect on employee involvement in Ministerio Agricultura e Pescas, meaning that the work environment is anything that is in the environment that can affect either directly or indirectly a person or group of people in carrying out their activities in the organization.

Teamwork not significant positive effect on employee performance Ministerio Agricultura e Pescas, meaning that an effective team is a team that allows its members to be able to produce task completion that is greater in number than the results of individual work because the results of his work are the result of the contribution of team members together- the same but the teamwork at Ministerio Agricultura e Pescas does not fully work in supporting performance. 
Teamwork significant positive effect on employee involvement Ministerio Agricultura e Pescas, meaning that employee involvement has a significant positive effect on employee performance Ministerio Agricultura e Pescas, meaning that employees involve at all levels of the organization in decision making and problem solving (can be ideas, suggestions, criticism, etc. .

The role of employee involvement fully mediates the relationship of the work environment to employee performance is defined as the degree to which a person feels identical to work, where the work involvement of employees Ministerio Agricultura e Pescas feels compelled to do his job.

The role of employee involvement fully mediates the relationship of work teamwork to employee performance, meaning that work involvement in a specific work context is more focused on how current work can provide satisfaction with someone at present, whereas work involvement in a general context (generalized work context) is more directed at the value given from the work to his life. Work involvement employee of Ministerio Agricultura e Pescas have the degree to which people are known from their work, participate actively in them, and consider their achievements important to respect.

\section{Implication}

Theoretically this research has been able to build a theoretical model about the role of employee involvement in mediating the work environment, teamwork on employee performance. The results of the model explain that the work environment, teamwork directly and indirectly does not affect employee performance. This research emphasizes the importance of employee involvement in mediating the work environment, teamwork on employee performance increases the performance of employees Ministerio Agricultura e Pescas.

Practically this research is very meaningful for employees, because of employee limitations, the results of this study are expected to provide an illustration that the work environment is an important determinant of employee performance. Although the environment does not directly affect performance, it actually influences employee involvement, which in turn affects employee performance.

For organizations, the results of this study provide clues to the importance of giving the role of employee involvement (job involvement) to each employee in the form of an employee's commitment, involving the role and concern for work, both physically, knowledgeally, and emotionally so that the work performed is very important, and have a strong belief to get the job done. Good teamwork, in improving employee performance. 


\section{Limitations}

This research was developed as an integrated model, but there are a number of limitations in this study that make this research imperfect. First, this research was only conducted at one of the Government Ministries so that respondents' perceptions were still too little. Second, pFurther research can be done on government or the private sector to be able to compare the work environment in other organizations.

\section{REFERENCES}

Adam \& Boateng, R. (2017) 'Virtualisation of an administrative work environment in higher education', Journal of Enterprise Information Management, 30(5), pp. 723-747.

Ahya, J. J. K. . (2016) Job Characteristcs, Work, Involvement, and Job Performance Of Public Servants, European Journal of Training and Development Iss Journal of Training and Development Iss European Journal of Training and Development.

Amin, M. (2014) 'The impact of human resource management practices on performance Evidence from a Public University', The TQM Journal, 26(2), pp. 125-142.

Anitha, J. 2014. Determinants of employee engagement and their impact on employee performance. International Journal of Productivity and Performance Management, 63(3), pp.308-323.

Arsalani, N. (2011) 'Adaptation of questionnaire measuring working conditions and health problems among Iranian nursing personnel', Asian Nursing Research. Elsevier, 5(3), pp. $177-182$.

Aziz, R. and Psikologi, F. (2015) 'Aplikasi modelrasch', 12(1999).

Farh, C. I. C. C., Seo, M. G. and Tesluk, P. E. (2012) 'Emotional Intelligence, Teamwork Effectiveness, and Job Performance: The Moderating Role of Job Context', Journal of Applied Psychology, 97(4), pp. 890-900.

Gil, F., Alcover, C. M. \& Peiró, J. M. (2005) 'Work team effectiveness in organizational contexts: Recent research and applications in Spain and Portugal', Journal of Managerial Psychology, 20, pp. 193-218.

Guinalíu, M. \& Jordán, P. (2016) 'Building trust in the leader of virtual work teams', Spanish 
Journal of Marketing - ESIC, 20(1), pp. 58-70.

Güngör, P. 2011. "The relationship between reward management system and employee performance with the mediating role of motivation: a quantitative study on global banks", 7th International Strategic Management Conference, Procedia Social and Behavioural Sciences, Vol. 24, pp. 1510-1520.

Hair, J.F.2014. Partial least squares structural equation modeling (PLS-SEM). European Business Review, 26(2), pp.106-121.

Hariandja, Marihot. 2006, Perilaku Organisasi, Bandung Unpar Press.

Henttonen, K., Janhonen, M. and Johanson, J. E. (2013) 'Internal social networks in work teams: Structure, knowledge sharing and performance', International Journal of Manpower, 34(6), pp. 616-634.

Jankingthong, Korkaew and Suthinee Rurkkhum, 2012, "Factors Affecting Job Performance : A Review of Literature, Silpakorn Thailand : Silpakorn University Journal of Social Sciences, Humanities and Arts Vol . 12 (2): 115-127, 2012.

Jayaweera, T. (2015) 'Impact of Work Environmental Factors on Job Performance, Mediating Role of Work Motivation: A Study of Hotel Sector in England', International Journal of Business and Management, 10(3), pp. 271-278.

Khan, R.U. ; Durrani, F.R. ; Chand, N. ; Anwar, H., 2010. Influence of feed supplementation with Cannabis sativa on quality of broilers carcass. Pakistan Vet. J., 30 (1): 34-38

Khan, M. R., Ziauddin, Jam, F. A., and Ramay, M. I., The Impacts of Organizational Commitment on Employee Job Performance, European Journal of Social Sciences, 15(3), 2010, pp. 292298

Khan, R.A.G., Khan, F.A. \& Khan, M.A., 2011. Impact of Training and Development on Organizational Performance. Global Journal of Management and Business Research, 11(7), pp.63-69.

Koopmans L, Bernaards CM, Hildebrandt VH, Schaufeli WB, De Vet HCW, Van der Beek AJ. Conceptual frameworks of individual work performance - A systematic review. Journal of Occupational and Environmental Medicine. 2011; 53(8): 856-866.

Lee, F., Lee, T., and Wu, W., 2010. The Relationship between Human Resource Management Practices, Business Strategy and Firm Performance: Evidence from Steel Industry in Taiwan. The International Journal of Human Resource Management, 21(9), pp. 1351-1372. 
Levi, D. and Slem, C. (1995) 'Team work in research and development organizations: The characteristics of successful teams', International Journal of Industrial Ergonomics, 16(1), pp. 29-42.

Lin, J. and Lee, P. (2011) 'Performance Management in Public Organizations : a Complexity Perspective', Public Management Review, 12, pp. 81-96.

M \& Rao, (2014) 'Job Involvement of Secondary School Teachers and Its Effect on Teaching Competency', International Journal of Education and Psychological Research (IJEPR, 3(2), pp. 50-53.

Mateo, R. (2013) 'Effects of tidy/messy work environment on human accuracy', Management Decision, 51(9), pp. 1861-1877.

Mathis, Robert L., \& Jackson, J. H. (2008). Human resource management. United States: Thomson Corporation.

Mahabeer, M. and Govender, P. (2012) 'Employee involvement and work team effectiveness: Biographical influences', Corporate Ownership and Control, 10 (1 D,Cont 3), pp. 353-362.

Mensah, J.K. 2015. A “coalesced framework" of talent management and employee performance: for further research and practice. International Journal of Productivity and Performance Management, 64(4), pp.1-24.

Meriläinen, M. and Kõiv, K. (2018) 'Bullying and an unfavourable working environment', International Journal of Workplace Health Management, 11(3), pp. 159-176.

Mina, \& Grigoru, C. (2013) 'A Human Resources Approach Regarding Combating Compulsive Bureaucracy in Governmental Institutions', Lumen International Conference Logos Universality Mentality Education Novelty (LUMEN, 92(Lumen), pp. 551-560.

Mohd, I. H., Mohd Shah, M. and Zailan, N. S. Z. (2016) 'How Work Environment affects the Employee Engagement in a Telecommunication Company', The European Proceeding of Social \& Behavioural Sciences, pp. 418-426.

Pawirosumarto, \& Gunawan, R. (2017) 'The effect of work environment, leadership style, and organizational culture towards job satisfaction and its implication towards employee performance in Parador hotels and resorts, Indonesia', International Journal of Law and Management, 59(6), pp. 1337-1358.

Permarupan, \& Saufi, R. A. (2013) 'Quality of work life on employees job involvement and affective commitment between the public and private sector in Malaysia', Asian Social 
Science, 9(7), pp. 268-278.

Rahati, A., Sotudeh-Arani, H., Adib-Hajbaghery, M., \& Rostami, M. (2015). Job Involvement and Organizational Commitment of Employees of Prehospital Emergency Medical System. Nursing and Midwifery Studies, 4(4), 1-6.

Rangus, K., Drnovšek, M. and Di Minin, A. (2016) 'Proclivity for open innovation: Construct development and empirical validation', Innovation: Management, Policy and Practice. Routledge, 18(2), pp. 191-211.

Raziq, A. and Maulabakhsh, R. (2015) 'Impact of Working Environment on Job Satisfaction', Procedia Economics and Finance. Elsevier B.V., 23(October 2014), pp. 717-725.

Robbins, Stephen P. \& Timothy A. Judge. (2008). Perilaku Organisasi Edisi ke-12, Jakarta.

Rohail, R. et al. (2017) 'Effects of Work Environment and Engagement on Nurses Organizational Commitment in Public Hospitals Lahore, Pakistan', Saudi Journal of Medical and Pharmaceutical Sciences, 3(7A), pp. 748-753.

Sadat, M. \& Fesharaki, H. (2012) 'The Influence of Employees' Involvement in Performance Assessment System on Employees ' Creativity', 2(11).

Samson, G. ., Waiganjo, M. and Koima, J. (2015) 'the Effect of Workplace Environment on Employee Performance', International Journal of Managerial Studies and Research (IJMSR), 3(12), p. 34.

Saputro, T. A., Paramita, (2016) 'Analysis the Influence of the Work Environment and Organizational Commitment to Job Satisfaction and Impact on Employee Job Performance (Studies at Directorate Officers Polytechnic Health Ministry In Semarang)', journal of Management, 02(02).

Smither R.D., Houston: Organization Development Strategies for Changing Environment. Harper and Collins Publisher. 1996. New York.

Sofijanova, \& Odredi, P. (2013). Employee Involvement and Organizational Performance: Evidence From the Manufacturing Sector in Republic of Macedonia. Trakia Journal of Sciences, 11(11), 31-36.

Sutrisno, Edy. 2013. Manajemen Sumber Daya Manusia, Cetakan Kelima. Yogyakarta: Prenada Media.

Tyagi, V. (2017) 'Working Environment- As a Predictor of Employee Engagement with reference 
ABM : International Journal of Administration, Business and Management, Vol. 2 No. 2 November 2020

to Academicians', Effulgence-A Management Journal, 14(2), p. 19.

Walter, J. K. et al. (2019) 'Teamwork When Conducting Family Meetings: Concepts, Terminology, and the Importance of Team-Team Practices', Journal of Pain and Symptom Management. American Academy of Hospice and Palliative Medicine. 